(C) Elsevier/INRA

Original article

\title{
Selection on testis size as an indicator of maturity in growing animals. II Correlated responses in reproductive rate
}

\author{
WG Hill ${ }^{1}$, PJ Marks ${ }^{2}$, JC Jenkins ${ }^{1}$, RB Land ${ }^{2, \dagger}$ \\ ${ }^{1}$ Institute of Animal Genetics, University of Edinburgh, \\ West Mains Road, Edinburgh EH9 $3 J N$; \\ ${ }^{2}$ AFRC Institute of Animal Physiology and Genetics Research, \\ Edinburgh Research Station, Roslin, Midlothian EH25 9PS, UK*
}

(Received 2 October 1989; accepted 15 February 1990)

Summary - Selection was undertaken in replicated lines of mice for 11 generations high and low on 5 wk body weight (HX, LX), on 5 wk testis weight (XH, XL), and on indices in which body and testis weight were selected in the same (HH, LL), and in opposite directions (HL, LH). There were correlated responses in number born in the lst litter, with differences between pairs of lines averaged over replicates and the last 5 generations of: $\mathrm{HX}-\mathrm{LX}=2.2, \mathrm{XH}-\mathrm{XL}=2.5, \mathrm{HH}-\mathrm{LL}=1.0, \mathrm{HL}-\mathrm{LH}=-0.2$, each with standard error of 0.6 . The control mean litter size was 10.3 . Differences were only partly removed by phenotypic correction for body weight, and limited data indicated that ovulation rate responded little more than litter size. Previous experiments suggesting that litter size can be changed by selecting on testis size are confirmed, but some of this response is associated with body weight change.

reproduction / growth / testis / selection / mouse

Résumé - Sélection sur la taille des testicules considérée comme un indicateur de la maturité des animaux en croissance. II Réponses corrélées sur les performances de reproduction. Une expérience de sélection chez la souris a été conduite pendant 11 générations, vers le haut (H) et vers le bas (L) selon plusieurs critères: masse corporelle chez le mâle à 5 semaines (lignées $H X, L X)$; masse testiculaire à 5 semaines $(X H, X L)$; indices combinant ces deux caractères, dans le même sens $(H H, L L)$ ou en sens opposés (HL, LH). Chaque expérience a été répétée 2 fois. Des corrélations entre le nombre d'animaux nés en première portée et les critères cités ci-dessus ont été observées. En moyenne les différences entre lignées haute et basse ont été les suivantes, pour les cinq dernières générations: $H X-L X=2,2 ; X H-X L=2,5 ; H H-L L=1,0 ; H L-L H=-0,2 ;$ avec un écart type de 0,6. La taille de portée moyenne dans les 4 lignées témoins était de 10,3. Les différences ne sont que partiellement supprimées par une correction phénotypique tenant compte de la masse corporelle, et des données partielles indiquent que la réponse est légèrement plus élevée sur le taux d'ovulation que sur la taille de portée. Les résultats d'expériences antérieures suggérant que la taille des portées pouvait être modifiée par

* Formerly AFRC Animal Breeding Research Organisation 
une sélection à partir de la taille des testicules sont confirmés, mais cette réponse est partiellement associée à une modification de la masse corporelle.

reproduction / croissance / testicule / sélection / souris

\section{INTRODUCTION}

It has been suggested that, because the same hormones are involved in gonadal development and pituitary response in both males and females, testis size of the male is an indicator of ovulation rate and thus litter size of his female relatives (Land, 1973). In a previous experiment with mice (Islam et al, 1976), selection on testis weight at 11 wks gave a correlated response in ovulation rate but not in litter size. Similarly, correlated response in testis size was obtained from selection for ovulation rate in pigs, but this was not associated with any substantial change in litter size (Cunningham et al, 1979; Johnson and Neal, 1988). Selection in sheep for juvenile testis size, corrected for body weight, led to little or no change in ovulation rate but to more pronounced responses in mature body weight (Land et al, 1980; Haley et al, 1989). Other workers have found some evidence of a correlation between testis size and litter size or ovulation rate in sheep (Ricordeau et al, 1979, 1986; Purvis et al, 1988), cattle (Toelle and Robison, 1985a) and pigs (Schinckel et al, 1983; Toelle and Robison, 1985b; see Haley et al (1989) for review). Selection for litter size in mice led to correlated changes in testis weight, even after adjustment for body weight (Eisen and Johnson, 1981).

The present experiment was designed to evaluate the efficacy of selection on testis size as an indicator of degree of maturity, with the aim of changing the relation between early growth rate and mature size. Selection was practised high and low on body weight, on testis weight, and on indices in which selection was practised in the same and opposite directions, all on mice of $5 \mathrm{wks}$ of age. The responses in testis size and body weight at different ages are reported elsewhere (Hill et al, 1990). Because body size is itself correlated with both testis size and ovulation rate, this experiment provides an opportunity to clarify the relationships among the traits.

\section{MATERIAL AND METHODS}

The stocks used and basic design of the experiment are described in detail by Hill et al (1990). In summary, there were 8 selected lines and 2 unselected control lines, each replicated twice, maintained in 4 contemporary groups each of 4 selected lines (either all single trait or all index) and 1 control. Selection was practised for high or low body weight alone or males at 5 wks of age (lines designated HX, LX, respectively), for high or low testis weight alone of hemicastrated males at 5 wks of age $\left(\mathrm{XH}_{2} \mathrm{XL}\right)$, or for indices with both these traits selected in the same (index 1$\mathrm{HH}, \mathrm{LL}$ ), or in the opposite directions (index 2-HL, LH) (Land et al, 1980; Lee and Land, 1985, Haley et al, 1989; Lee and Haley, 1990). Males were selected within full sib families and females were sampled at random within families, as were males of the controls (designated CC). There were 8 full sib families per line. Selection was undertaken on each generation, except 7, until generation 12, $i e$ for 11 generations in all. 
Litter size in first parity was recorded every generation on each family and on spare matings, usually a total of 12 in each line, and at generation 13 body weight at mating was recorded and more matings were set up. (Generation number in this paper refers to that of the offspring, ie litter size of generation 1 implies unselected dams mated to selected sires.) At generation 8, an extra group of females were taken for more detailed analysis, and at approximately 9 wks of age they were mated to males of the same line and observed daily for vaginal plugs. At $d 17$ of gestation (plug at $d 0$ ) these mice were sacrificed and the ovaries and uterus excised. Corpora lutea as an estimate of ovulation rate and the number of live foetuses were counted, and prenatal mortality calculated as their ratio ( $i e$ assuming all ova were fertilized).

Statistical analysis was undertaken as by Hill et al (1990). In essence the error variance was computed from the variation between replicates of lines selected in the same way. The error has only 8 degrees of freedom, but includes both drift variation between replicates and variation between mice within replicates.

\section{RESULTS}

The litter size of each generation during the period of selection is shown in figures 1 and 2, averaged over replicates. Individual replicate means are given in table I for the last few generations (9-12) as a simple summary of the responses, which includes most information since responses accumulate. Table I also contains estimates of litter size and body weight of the female at mating when recorded in generation 13. Contrasts among pairs of lines, eg HX-LX between the high and low body weight selected lines, are given in table II, which includes results pooled over generations 913. As lines had approximately the same effective population size, most inbreeding effects should be removed by comparing litter sizes of high and low lines.
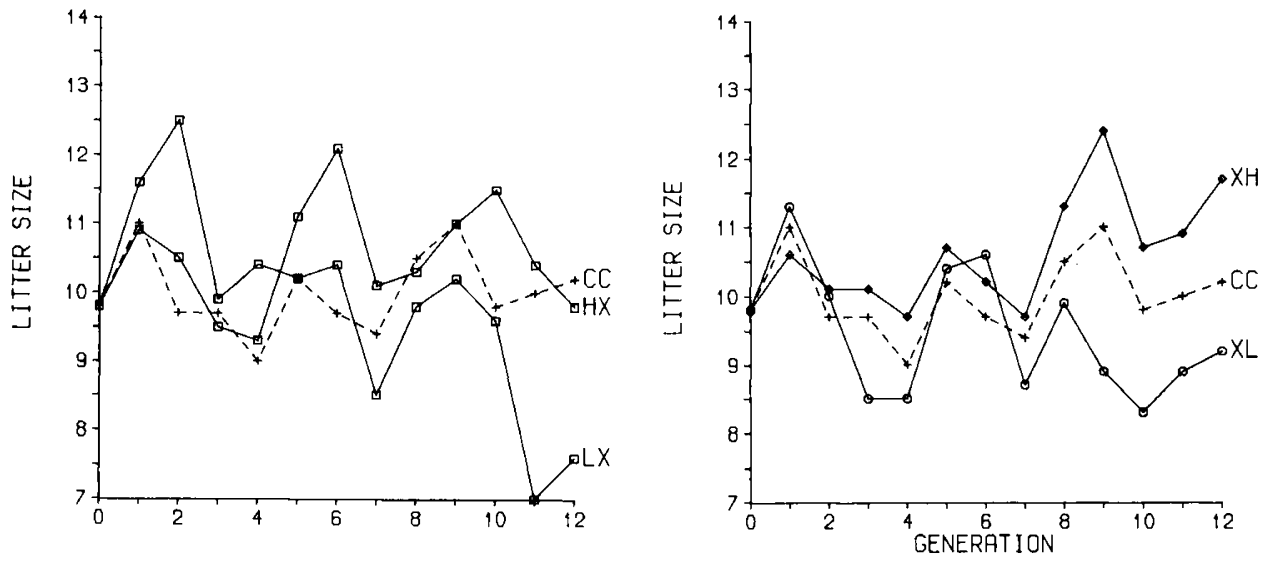

Fig 1. Litter size in first parity averaged over replicates: left graph, for lines selected on body weight (HX, LX), right graph for lines selected on testis weight (XH, XL), with their corresponding controls (CC). 
Table I. Litter size (LS) averaged over generations 9-12 ( $n=81-94$ per line, summed over replicates) and at generation $13(n=16-22)$; mating weight $(\mathrm{MW})$ at generation 13; number of failed matings (FM, of $n=96$ matings made) summed over generations 9-12. ${ }^{1} \mathrm{SE}$ estimated from between replicate variance, except ( ) estimated from within line binomial variance.

\begin{tabular}{|c|c|c|c|c|c|c|}
\hline \multirow{2}{*}{$\begin{array}{l}\text { Generation } \\
\text { Replicate } \\
\text { Trait }\end{array}$} & \multicolumn{3}{|c|}{ 9-12 average } & \multicolumn{2}{|c|}{13} & \multirow{2}{*}{$\begin{array}{c}9-12 \text { sum } \\
\text { sum } / 96 \\
\text { FM }\end{array}$} \\
\hline & $\begin{array}{c}1 \\
L S\end{array}$ & $\stackrel{2}{L S}$ & $\begin{array}{c}\text { Mean } \\
L S\end{array}$ & $\begin{array}{c}M e a n \\
M W(g)\end{array}$ & $\begin{array}{c}\text { Mean } \\
L S\end{array}$ & \\
\hline $\begin{array}{l}\mathrm{HX} \\
\mathrm{LX} \\
\mathrm{XH} \\
\mathrm{XL} \\
\mathrm{CC}\end{array}$ & $\begin{array}{r}11.3 \\
8.9 \\
12.4 \\
8.9 \\
10.9\end{array}$ & $\begin{array}{r}10.0 \\
8.3 \\
10.5 \\
8.7 \\
9.6\end{array}$ & $\begin{array}{r}10.7 \\
8.6 \\
11.4 \\
8.8 \\
10.2\end{array}$ & $\begin{array}{l}28.0 \\
23.1 \\
29.4 \\
25.0 \\
27.6\end{array}$ & $\begin{array}{r}11.2 \\
8.7 \\
11.4 \\
9.2 \\
10.7\end{array}$ & $\begin{array}{r}3 \\
7 \\
5 \\
15 \\
9\end{array}$ \\
\hline $\begin{array}{l}\text { HH } \\
\text { LL } \\
\text { HL } \\
\text { LH } \\
\text { CC }\end{array}$ & $\begin{array}{r}9.1 \\
9.0 \\
10.7 \\
11.1 \\
10.1\end{array}$ & $\begin{array}{r}10.9 \\
8.6 \\
9.7 \\
9.6 \\
10.0\end{array}$ & $\begin{array}{r}10.0 \\
8.8 \\
10.2 \\
10.3 \\
10.1\end{array}$ & $\begin{array}{l}27.8 \\
24.1 \\
27.4 \\
24.0 \\
25.8\end{array}$ & $\begin{array}{r}9.9 \\
9.5 \\
10.6 \\
11.0 \\
10.9\end{array}$ & $\begin{array}{r}6 \\
11 \\
12 \\
4 \\
7\end{array}$ \\
\hline $\mathrm{SE}^{1}$ & & & 0.5 & 1.3 & 0.8 & $(2.7)^{1}$ \\
\hline
\end{tabular}
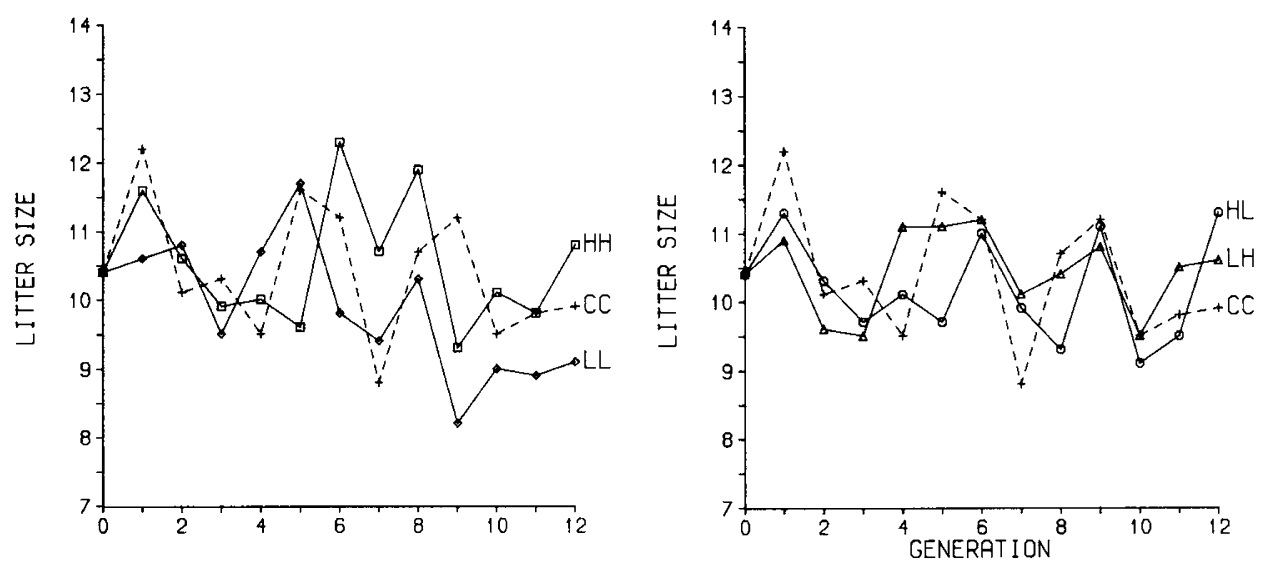

Fig 2. As fig 1 but: upper graph for lines selected on index 1 (HH, LL), lower graph for lines selected on index 2 (HL, LH).

There was a consistent divergent response in litter size associated with selection on body weight alone (HX-LX $=2.2$ born, averaged over generations 9-13, from table II), on testis weight alone $(\mathrm{XH}-\mathrm{XL}=2.5)$ and, although less, also on index 1 $(\mathrm{HH}-\mathrm{LL}=1.0)$ where the 2 traits were selected in the same direction. The response in litter size on the antagonistic indices (HL-LH $=-0.2)$ was small. A difference of 2 mice is equivalent to about $20 \%$ of the mean, or 0.8 phenotypic standard deviations. Fitting a phenotypic regression on weight at mating reduced, but did not eliminate, 
Table II. Contrasts of: litter size (LS) averaged over generations 9-13; litter size before (LS) and after (adj LS) adjustment for mating weight at generation 13; ovulation rate and live foetus number before (OR, LF) and after (adj OR, adj LF) adjustment for 5 wk body weight and prenatal survival at generation 8 (replicates pooled). ${ }^{*} P<0.05,{ }^{* *} P<0.01$; ${ }^{1}$ Generation 9-12 and 13 pooled from table I; ${ }^{2}$ Litter sizes and mating weights given in table I; ${ }^{3}$ Components of litter size and 5 wk weights given in table III; ${ }^{4} \mathrm{HBW}-\mathrm{LBW}$ is the mean difference between all lines selected high and low on body weight, and similarly HTW-LTW for lines selected on testis weight.

\begin{tabular}{|c|c|c|c|c|c|c|c|c|}
\hline Generations & $\begin{array}{l}9-13 \\
L S^{1}\end{array}$ & $\begin{array}{c}19 \\
L S^{2}\end{array}$ & $\stackrel{13}{\operatorname{adj} L S^{2}}$ & $\stackrel{8}{O R^{3}}$ & $\stackrel{8}{F^{3}}$ & $\stackrel{8}{P} S^{3}$ & $\operatorname{adj} \stackrel{8}{O} R^{3}$ & $\stackrel{8}{\operatorname{adj} L F^{3}}$ \\
\hline $\begin{array}{l}\text { HX-LX } \\
\text { XH-XL } \\
\text { HH-LL } \\
\text { HL-LH }\end{array}$ & $\begin{array}{l}2.2^{* *} \\
2.5^{* *} \\
1.0 \\
-0.2\end{array}$ & $\begin{array}{c}2.5^{*} \\
2.2 \\
0.4 \\
-0.4\end{array}$ & $\begin{array}{r}1.6 \\
1.4 \\
-0.3 \\
-1.0\end{array}$ & $\begin{array}{l}1.1 \\
1.7 \\
2.6^{*} \\
0.8\end{array}$ & $\begin{array}{l}0.2 \\
1.9^{*} \\
1.6 \\
-0.7\end{array}$ & $\begin{array}{r}0.00 \\
0.02 \\
0.00 \\
-0.10\end{array}$ & $\begin{array}{l}1.0 \\
0.5 \\
0.9 \\
0.4\end{array}$ & $\begin{array}{r}0.2 \\
1.1 \\
0.5 \\
-0.9\end{array}$ \\
\hline SE & 0.6 & 1.1 & 0.9 & 1.2 & 0.9 & 0.08 & 1.1 & 1.0 \\
\hline $\begin{array}{l}\text { HBW-LBW } \\
\text { HTW-LTW }\end{array}$ & $\begin{array}{l}1.0^{*} \\
1.2^{* *}\end{array}$ & $\begin{array}{l}0.8 \\
1.0\end{array}$ & $\begin{array}{l}0.1 \\
0.7\end{array}$ & $\begin{array}{l}1.5^{*} \\
1.2\end{array}$ & $\begin{array}{l}0.4 \\
1.4^{*}\end{array}$ & $\begin{array}{r}-0.03 \\
0.04\end{array}$ & $\begin{array}{l}0.8 \\
0.3\end{array}$ & $\begin{array}{r}-0.1 \\
0.8\end{array}$ \\
\hline $\mathrm{SE}$ & 0.3 & 0.6 & 0.5 & 0.7 & 0.5 & 0.05 & 0.6 & 0.5 \\
\hline
\end{tabular}

the high-low contrasts, regardless of whether the lines had been selected on body weight or testis weight (table II).

Results of the more detailed study of components of litter size conducted earlier at generation 8 are given in table III, with contrasts summarised in table II. The differences in litter size (ie number of live embryos) were largest in the testis weight single (XH-XL) and index lines (HH-LL), and reduced but not eliminated by correction for body weight. The body weight (HX-LX) lines differed little in litter size or in body weight, the latter a quirk of this generation as responses were generally obtained (Hill et al, 1990). Ovulation rate differences were similar to or greater than those for litter size, and not completely removed by regression; but the HL-LH difference was positive for ovulation rate and negative for litter size. There was no obvious pattern in prenatal survival (table III).

Insofar as any trend was detectable in numbers of failed matings, these generally occurred in lines selected for low testis weight (table I).

\section{DISCUSSION}

It has been widely established that selection for body size in mice gives correlated responses in litter size ( $e g$ Falconer, 1973; Eisen, 1978) and similar results have been obtained in lines selected in this laboratory from the same base population (Brien et al, 1984). Evidence in other species is more equivocal: for example the genetic correlation between body size and litter size in pigs appears to be small (Legault, 1971; Morris, 1975), but there are few estimates. In our previous experiment in which selection was practised for testis weight at $11 \mathrm{wks}$, a positive correlated response in ovulation rate and body weight was obtained, but litter size increased in 
Table III. Components of litter size at generation 8 (replicates pooled): Nos of mice mated $\left(\mathrm{N}_{\mathrm{M}}\right)$ and pregnant $\left(\mathrm{N}_{\mathrm{P}}\right)$, their 5 wk body weight $(\mathrm{BW})$, ovulation rate $(\mathrm{OR})$, No of live foetuses at $18 \mathrm{~d}$ of gestation (LF) and prenatal survival (PNS $=\mathrm{LF} / \mathrm{OR}$, computed for each mouse).

\begin{tabular}{lcccccc}
\hline Line & $N_{M}$ & $N_{P}$ & $B W(g)$ & $O R$ & $L F$ & $P N S$ \\
\hline HX & 26 & 24 & 21.9 & 14.6 & 10.9 & 0.79 \\
LX & 29 & 28 & 21.8 & 13.5 & 10.7 & 0.79 \\
XH & 39 & 36 & 23.9 & 15.5 & 12.3 & 0.80 \\
XL & 32 & 32 & 21.4 & 13.7 & 10.4 & 0.78 \\
CC & 34 & 32 & 22.5 & 13.9 & 11.3 & 0.83 \\
HH & 30 & 28 & 25.0 & 15.7 & 11.8 & 0.76 \\
LL & 31 & 27 & 21.6 & 13.1 & 10.1 & 0.76 \\
HL & 14 & 12 & 23.3 & 14.7 & 10.0 & 0.67 \\
LH & 39 & 35 & 22.6 & 13.9 & 10.7 & 0.77 \\
CC & 33 & 32 & 22.5 & 14.1 & 11.5 & 0.82 \\
SE & & & 0.8 & 0.8 & 0.6 & 0.05 \\
\hline
\end{tabular}

1 replicate and reduced in the other, with negligible mean change (Islam et al, 1976). No explanation other than sampling for this inconsistency between experiments, indeed between replicates, has been identified. Selection for ovulation rate in pigs has changed ovulation rate substantially, but not litter size (Cunningham et al, 1979; Johnson and Neal, 1988).

In the present experiment, positive correlated responses have occurred in litter size from selection on both $5 \mathrm{wk}$ body weight alone and on $5 \mathrm{wk}$ testis weight alone, leading to a divergence of some $20 \%$ of the mean in each case. Body weight and testis weight are, however, positively correlated, both phenotypically and, judging by most of our results (Hill et al, 1990), genetically. Our data on ovulation rate are much more scanty, but the indications are that it did not respond substantially more than did litter size because changes in embryonic survival were small. The $\mathrm{HH}$, LL index lines showed less correlated response in litter size than the single trait lines, the HL, LH index lines almost none. The data from Hill et al and table II are summarized in table IV.

It is not easy to combine these results into a coherent whole. The relative correlated response in litter size (L) to selection on body weight (W) or testis weight $(T)$ is, with equal selection intensities: $C_{L W} / C_{L T}=\left(r_{A L W} h_{W}\right) /\left(r_{A L T} h_{T}\right)$ where, for example, $C_{L W}, r_{A L W}$ and $h_{w}^{2}$ denote the correlated response in litter size to selection on body weight, the genetic correlation of these traits and the heritability of body weight, respectively (Falconer, 1989). For the single trait selection, taking $\mathrm{h}_{\mathrm{W}}^{2}=0.26$ and $\mathrm{h}_{\mathrm{T}}^{2}=0.48$ from within family selection (Hill et al, 1990), $\mathrm{r}_{\mathrm{ALW}} / \mathrm{r}_{\mathrm{ALT}}=1.2$. The other indication that both traits were similarly correlated is from the selection on index $2(\mathrm{HL}, \mathrm{LH})$, where little correlated response was observed in litter size. The smaller correlated response in litter size to HH, LL selection is surprising because the divergence between them in both body weight 
Table IV. Summary of means and contrasts of selected traits in generations 10-12 and primiparous litter size in generations $9-13 .{ }^{1}$ Generation 11 means only for CC, HX and LX testis weight which was not recorded in generations 10 and 12 of these lines. The body weights for generation 11 only were $\mathrm{CC}=23.2 \mathrm{~g}, \mathrm{HX}-\mathrm{LX}=3.4 \mathrm{~g}$.

\begin{tabular}{lccc}
\hline & \multicolumn{2}{c}{ Males } & $\begin{array}{c}\text { Females } \\
\text { Litter size }\end{array}$ \\
\hline CC mean & $5 w k$ body $w t(g)$ & 5 wk testis $w t(m g)$ & 10.3 \\
HX-LX & 23.1 & $57^{1}$ & 2.2 \\
XH-XL & 4.6 & $20^{1}$ & 2.5 \\
HH-LL & 4.0 & 37 & 1.0 \\
HL-LH & 3.4 & 31 & -0.2 \\
\hline
\end{tabular}

and testis weight was similar to that in the single trait lines, but this could just be a sampling error (table II).

The overall conclusion from this experiment, which agrees with findings of Eisen and Johnson (1981), is that both body weight and testis weight influence litter size independently. In the accompanying paper (Hill et al, 1990) it was shown that selection for increased testis size in immature animals led to a small reduction in mature weight. This result, coupled with the increased litter size, suggests that selection for testis size can lead to increased female reproductive efficiency, as found by Lee and Haley (1990) with sheep, but that it should be regarded as a supplement to, rather than replacement for, direct selection on litter size.

\section{ACKNOWLEDGMENTS}

This work was supported by a grant from the Agricultural and Food Research Council. We are very grateful to Roberta Wallace, Ann Walker and staff of the mouse house for technical assistance, and to Gene Eisen, Douglas Falconer and Chris Haley for comments on a draft of this paper. Roger Land initiated the experiment reported here and died after lab work had been completed. He is greatly missed.

\section{REFERENCES}

Brien FD, Sharp GL, Hill WG, Robertson A (1984) Effects of selection on growth, body composition and food intake in mice. II. correlated responses in reproduction. Genet Res 44, 73-85

Cunningham PJ, England ME, Young LD, Zimmerman DR (1979) Selection for ovulation rate in swine: correlated responses in litter size and weight. $J$ Anim Sci 48, 509-516

Eisen EJ (1978) Single-trait and antagonistic index selection for litter size and body weight in mice. Genetics $88,781-811$ 
Eisen EJ, Johnson BH (1981) Correlated responses in male reproductive traits in mice selected for litter size and body weight. Genetics 99, 513-524

Falconner DS (1973) Replicated selection for body weight in mice. Genet Res 22, 291-321

Falconer DS (1989) Introduction to Quantitative Genetics. 3rd edn, Longman, Harlow

Haley CS, Lee GJ, Fordyce M, Land RB (1989) Selection for testis size adjust for body weight in male lambs: Direct responses in males and correlated responses for reproduction in females. J Reprod Fert (submitted)

Hill WG, Marks PJ, Jenkins JC, Land RB (1990) Selection on testis size as an indicator of maturity in growing animals. Genet Sel Evol 22, 229-244

Islam ABMM, Hill WG, Land RB (1976) Ovulation rate of lines of mice selected for testis weight. Genet Res 27, 23-32

Johnson RK, Neal SM (1988) Opportunities and possible methods to improve reproduction in the pig. In: Animal Breeding Opportunities. Occasional Publication British Society of Animal Production. 12, 221-237

Land RB (1973) The expression of female sex limited characters in the male. Nature $241,208-209$

Land RB, Carr WR, Lee GJ (1980) A consideration of physiological criteria of reproductive merit in sheep. In: Selection Experiments in Laboratory and Domestic Animals (Robertson A, ed) Commonwealth Agricultural Bureaux, Slough, 147-157

Lee GJ, Land RB (1985) Testis size and LH response to LH-RH as male criteria of female reproductive performance. In: Genetics of Reproduction in Sheep (Land RB, Robinson DW eds) Butterworths, London, 333-341

Lee GJ, Haley CS (1990) Body weight adjusted testis size as a selection criterion to improve production efficiency in sheep. Proc 4th World Congr Genet Appl Livest Prod (in press)

Legault C (1971) Relationship between reproductive performance and fattening and carcass characters in the pig. Ann Genet Sel Anim 3, 153-160

Morris CA (1975) Genetic relationships of reproduction with growth and with carcass traits in British pigs. Anim Prod 20, 31-44

Purvis IW, Piper LR, Edey TN, Kilgour RJ (1988) The genetic relationship between ovulation rate and testicular diameter in a random-breeding Merino flock. Livest Prod Sci 18, 35-54

Ricordeau G, Pelletier J, Courot M, Thimonier J (1979) Phenotypic and genetic relationships between endocrine criteria and testicular measurements of young Romanov rams and the ovulation rates at 8 months of their half-sisters. Ann Genet Sel Anim 11, 145-159

Ricordeau G, Poivey JP, Bodin L, Barillet M, Roussely M (1986) Importance of testicular measurements on young males tested on individual performance for improvement of their daughters' prolificacy: application to the selection scheme on Lacaune milking breed. In: Proc 3rd World Congr on Genetics Applied to Livestock Production. University of Nebraska, Lincoln, USA 11, 72-77 
Schinckel A, Johnson RK, Pumphrey RA, Zimmerman DR (1983) Testicular growth in boars of different genetic lines and its relationship to reproductive performance. J Anim Sci 58, 1065-1076

Toelle VD, Robison OW (1985a) Estimates of genetic correlations between testes measurements and female reproductive traits in cattle. J Anim Sci 60, 89-100

Toelle VD, Robison OW (1985b) Estimates of genetic relationship between testes measurements and female reproductive traits in swine. $Z$ Tierz Züchtungsbiol $102,125-132$ 